\section{'San Zanobi' and 'Plinio' Elm Trees}

\author{
A. Santini ${ }^{1}$, A. Fagnani ${ }^{2}$, F. Ferrini ${ }^{2}$, and L. Mittempergher ${ }^{3}$ \\ Istituto per la Protezione delle Piante, C.N.R. Florence P.le Cascine 2850144 \\ Florence, Italy
}

Additional index words. tree breeding, Ulmus, Dutch Elm Disease

Elm (Ulmus L.) has been utilized by humans since prehistoric times for food, medicine, fiber, fodder for cattle, timber for construction, firewood, and [in the Mediterranean Basin from ancient Roman times (Columella $\approx 60$ C.E.) to the mid-20th century] as a living support for grapevine. In the last three centuries, elm has also been widely used as an ornamental tree to embellish the avenues and gardens of Europe, North America, and China. However, during the past century, this tree suffered major losses, with near-total disappearance of adult trees in some areas of the world as a result of two epidemic outbreaks of Dutch Elm Disease (DED), caused by two ascomycetes, Ophiostoma ulmi (Buisman) Nannf. and Ophiostoma novo-ulmi Brasier. The European elm species, U. glabra Huds., U. laevis Pall., U. procera Salisb. and U. minor Mill., are generally susceptible, although rare individuals of the last species and its hybrid $U$. $\times$ hollandica Mill. showed enough resistance to form the main basis of a breeding program (Heybroek, 1993). Ulmus pumila L., an Asian species introduced as an ornamental tree in the Mediterranean areas, proved to be moderately to highly resistant.

Another source of genes for resistance to the fungus that causes DED has been found in several species growing in central-eastern Asia, one of the most important centers of genetic diversity of Ulmus (Smalley and Guries, 1993). Unfortunately, the Asian species do not always meet ornamental and production requirements, or do not adapt easily to different environmental conditions. Consequently, the main breeding programs set up in Europe and in North America to develop DED-resistant trees involve cross-breeding of Asian with other indigenous species in order to produce individuals that combine the disease resistance of Asian elm with the growth characteristics and higher degree of environmental adaptability of European elm. 'San Zanobi' and 'Plinio' are two recent results of such research.

\section{Origin}

'San Zanobi' (Patent RM97 NV 0006) was selected among seedlings obtained by controlled pollination of Heybroek's 'Plantyn'

Received for publication 31 July 2001. Accepted for publication $10 \mathrm{Feb}$. 2002. The field work of Mr. Abdellah Dahmani is gratefully acknowledged.

${ }^{1}$ Researcher: to whom reprint requests should be addressed. E-mail: a.santini@ipp.cnr.it

${ }^{2}$ Undergraduate Technician.

${ }^{3}$ Professor (retired). elm (Heybroek, 1983) [(Ulmus glabra "Exoniensis" x Ulmus wallichiana $\mathrm{p} 39) \times(U$. minor $1 \times$ U. minor 28)] with $U$. pumila S.15. 'Plinio' (Patent RM 97 NV 0005) was obtained by controlled pollination of 'Plantyn' with $U$. pumila S.2.

Pollen from S.15 and S.2 was collected in a warm room from cut fruiting twigs, filtered and dried to $10 \%$ relative humidity (RH) (Mittempergher and La Porta, 1991). In January, the female flowers of 'Plantyn' were covered with terylene bags of adequate size tied to the branch to protect the flowers and prevent uncontrolled pollination. Pollination was carried out by forced air injection of pollen into the bags. The pollination bags were kept in place until fruit maturity.

\section{Description}

'San Zanobi' is monocormic and shows exceptionally rapid growth on fertile soils and in temperate climates, suggesting that it could be used for production of construction timber (Table 1). Its habit is cone-shaped with pronounced apical dominance, resulting in limited lateral branching on the developing shoots of the current season's growth (Fig. 1). The crown is therefore narrow and columnar. Apical dominance is so marked that seedlings rarely need pruning or training. The trunk is straight, long, and the bark is grey-green [ $\mathrm{n}^{\circ} 197 / \mathrm{c}$ Royal Horticultural Society (RHS), 1966].

The alternating deciduous leaves remain green in fall and are shed late. Their margins are often undulate; green-yellowish in color (RHS 147/c). The second leaf of the short shoot is roughly elliptic or oval, with an acute apex and the base is asymmetric. The petiole is glabrous and 6-9 $\mathrm{mm}$ long. Rather slender twig is hairless and grey-green in color (RHS 197/a). Vegetative buds are small $(<2 \mathrm{~mm}$ different for LSD test $(P<0.05)$. diam.), covered by only 3-4 perules; dark brown (RHS 200/b); rounded at the base of the long shoot and in the short shoot. The apical bud of the short shoot is larger than the subdominant buds and it is typically oblique and inward-folded. Corky wings are absent. Flowering starts late, only from the fifth year of age on selfrooted trees. Fruits are ovateroundish sessile samara measuring $1.5 \times 1.8$ $\mathrm{cm}$. Flushing occurs at the same time or only slightly later than in Ulmus minor Mill..

The name 'San Zanobi' comes from the reported prodigious flushing of a dead elm, acknowledgement of the passage of the relics of the saint bishop St. Zenobius, coming from outside town to the Florence (Italy) Cathedral during the year 429 C.E.; the event is commemorated by a marble stele flanking the Baptistry.

'Plinio' grows rapidly, although slightly slower than 'San Zanobi', roughly similar to that of fast-growing benchmark 'Lobel' (Table 1). It adapts readily to Mediterranean mountainous climates of Northern Italy (unpub. data). 'Plinio' is used as an ornamental shade tree (Fig. 2). The crown is about oval in 5-year-old trees. In isolated trees, the width of the crown can be up to $70 \%$ of its height. The trunk is straight, at times slightly sinuous, short. Branching begins at a height of 2-3 m. The bark is grey-green (RHS 198/ a) and is still smooth in 5-year-old trees. Leaves are alternating and deciduous, remaining green and active on the tree longer than is usual in other elms. The leaf blade is glabrous on both surfaces. Tertiary venation is rare. The leaf has a biserrate margin; an acute apex, and a noticeably asymmetric base. Color = yellowish green (RHS 147/a). The second leaf of the short shoot is broadly elliptic or oval. The petiole is glabrous and 6$9 \mathrm{~mm}$ long. The branches are rather slender; the glabrous twig is grey-green in color (RHS 197/a). Vegetative buds are fairly large (2-3 $\mathrm{mm}$ diam.), ovoid, with a non-pointed tip, and dark brown in color (RHS 200/a). The apical bud of the short branch is inwardfolded. Corky wings are absent. Flowering starts early, from the third year of age and is abundant. Fruits are ovate-roundish sessile samara with central seed measuring $2 \times 2 \mathrm{~cm}$. Flushing occurs a few days after that of Ulmus minor.

Table 1. Mean annual increments in height $(\mathrm{cm})$ and diameter $(\mathrm{cm})$ of the selections compared to the Dutch release 'Lobel', which was included as a benchmark for vigor. Data refer to plants obtained from self-rooted cuttings. Values were obtained from the mean of measurements made during the first 6 years of age in four experimental plots.

\begin{tabular}{|c|c|c|c|c|}
\hline Cultivar & $\mathrm{N}^{2}$ & Mean & STD $^{\mathrm{x}}$ & $\mathrm{Cv} \%{ }^{\mathrm{w}}$ \\
\hline \multicolumn{5}{|c|}{ Height increment $(\mathrm{cm}) \quad(F=12.53 ; P \leq 0.001)$} \\
\hline S. Zanobi & 84 & 122.0 & 23.73 & $19.4 \mathrm{c}$ \\
\hline Plinio & 45 & 104.9 & 47.11 & $44.9 \mathrm{~b}$ \\
\hline Lobel & 24 & 79.4 & 39.41 & $49.6 \mathrm{a}$ \\
\hline \multicolumn{5}{|c|}{ Diameter increment $(\mathrm{cm}) \quad(F=7.48 ; P \leq 0.001)$} \\
\hline S. Zanobi & 84 & 1.75 & 0.47 & $26.7 \mathrm{a}$ \\
\hline Plinio & 45 & 1.44 & 0.49 & $35.0 \mathrm{~b}$ \\
\hline Lobel & 24 & 1.46 & 0.48 & $32.8 \mathrm{~b}$ \\
\hline
\end{tabular}

${ }^{2} \mathrm{~N}=$ number of samples; ${ }^{x} \mathrm{STD}=$ Standard deviation; ${ }^{\mathrm{w}} \mathrm{CV} \%=$ Percent coefficient of variation. Means not sharing same letters are significantly 
The name 'Plinio' derives from the Roman naturalist and historian Pliny the Elder of the first century C.E., who wrote about elm in his "Naturalis Historia".

'San Zanobi' and 'Plinio' are easily propagated from hardwood cuttings taken in January and February, quickly dipped in EtOH 30\% solution containing IBA $3000 \mathrm{ppm}$, and placed in warm beds at $18^{\circ} \mathrm{C}$ in a mixture of 1 peat : 1 perlite : 1 sand (v/v/v). Rooting generally occurs within 4 weeks.

\section{Disease resistance}

Two-year-old seedlings of 'Plinio' and 'S.Zanobi' grown in the nursery were planted in the field in 1983 and 1984, respectively. During the third week of May, the time period that elm trees are at their highest susceptibility in this climate, in the second year of

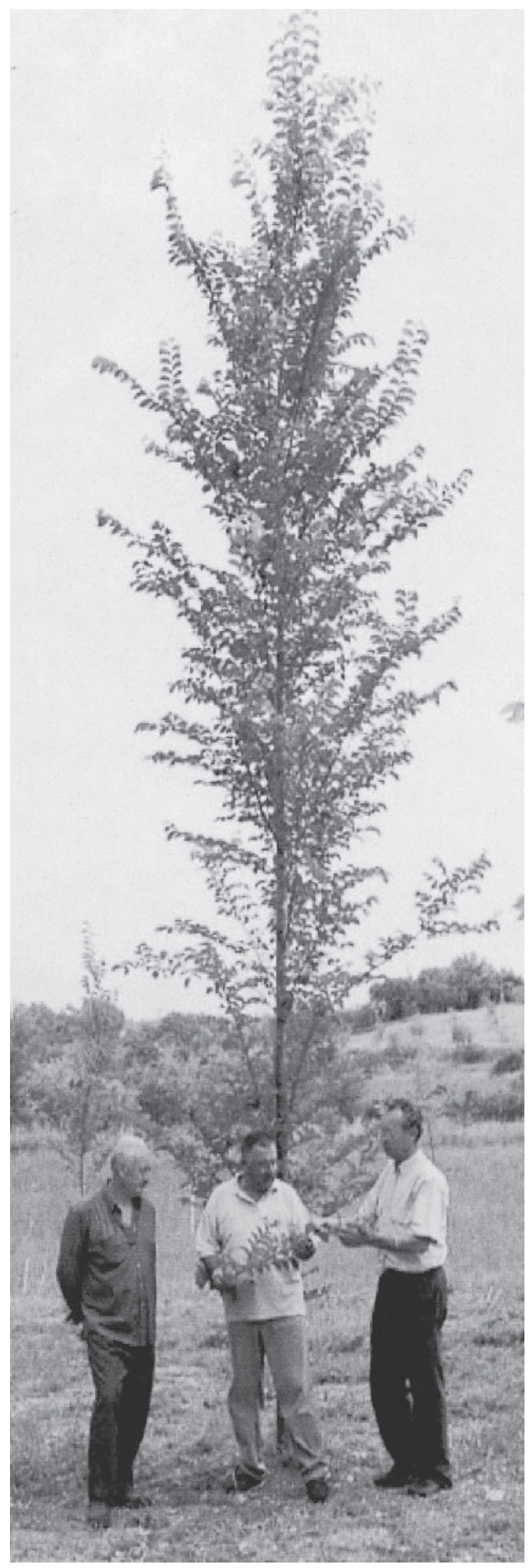

Fig. 1. The 'S. Zanobi' elm. growth in the field (4-year-old plants), trees were inoculated in the upper third of the main stem. Inoculation was performed with a single wound per plant, by cutting through the bark to the younger wood using a knife blade carrying two drops of a $0.2 \mathrm{~mL}$ of a $1 \times 10^{6} \mathrm{~mL}$ fungal spore mixed suspension of yeast phase cells, so that the inoculum would be absorbed by the tree's rising sap. The spore suspension, consisting of two tester isolates of the subsp. novo-ulmi and subsp. americana of $O$. novo-ulmi (Brasier and Kirk, 2001) found to be very aggressive in previous assays, were prepared by inoculating 50-mL Erlenmeyer flasks containing $10 \mathrm{~mL}$ of modified Tchernoff's liquid medium (Brasier, 1981), and incubating for $2 \mathrm{~d}$ on a shaker at room temperature. Spore concentration was then adjusted with sterile water to $1 \times 10^{6} \mathrm{~mL}$.

Symptoms of disease (percent of defoliation and percent of dieback) were observed after 4 weeks and at 3 (not reported) and 8 months by three independent assessors. Seedlings presenting less than $10 \%$ dieback were vegetatively propagated and planted out the following year in a completely randomized block design. Twelve rooted cuttings perclone, divided into three blocks, were used. Inoculations and disease evaluations were performed as described above and the symptoms, were compared with clones having known DED responses ('Lobel', moderately resistant; 'Urban' resistant; and CNR 118 highly susceptible). The resistance levels of the clones described here were significantly higher than the resistance levels of 'Lobel' and 'Urban' (Table 2).

Elm Yellows infections have to date never been reported in these selections (Mittempergher, 2000). Strong winds have not caused injury in any individual of these selections.

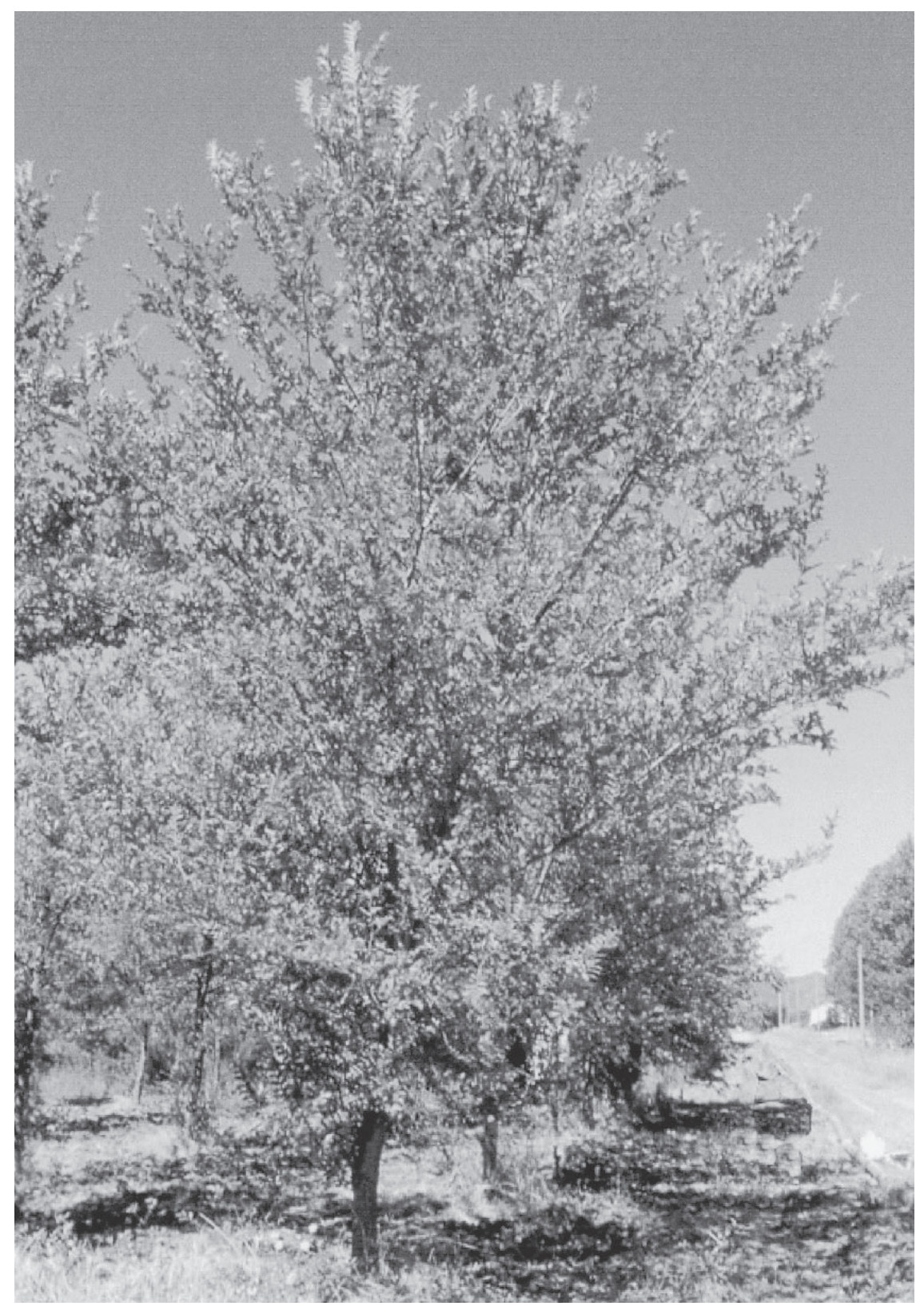

Fig. 2. The 'Plinio' elm. 
Table 2. Descriptive statistics of defoliation (symptoms assessed 4 weeks after inoculation) and dieback (symptoms assessed 8 months after inoculation) of 'Plinio', 'Lobel' (intermediately resistant), and CNR 118 (rated strongly susceptible in previous tests) (inoculation year 1990) and 'S. Zanobi', 'Lobel', 'Urban' (resistant) and CNR118 (inoculation year 1991), respectively, grown and inoculated in the same year and at the same location. Angles were used as a normalizing transformation for statistical analysis.

\begin{tabular}{|c|c|c|c|c|}
\hline Cultivar & $\mathrm{N}^{\mathrm{z}}$ & Mean & $\mathrm{STD}^{\mathrm{x}}$ & $\mathrm{CV} \%{ }^{\mathrm{w}}$ \\
\hline \multicolumn{5}{|c|}{1990 Inoculation } \\
\hline \multicolumn{5}{|c|}{ Defoliation $(F=551.1 ; P \leq 0.001)$} \\
\hline Plinio & 12 & 7.8 & 5.65 & $72.4 \mathrm{a}$ \\
\hline Lobel & 12 & 26.0 & 8.76 & $33.6 \mathrm{~b}$ \\
\hline CNR 118 & 12 & 95.0 & 2.36 & $2.5 \mathrm{c}$ \\
\hline \multicolumn{5}{|c|}{$\operatorname{Dieback}(F=1095.1 ; P \leq 0.001)$} \\
\hline Plinio & 12 & 3.9 & 2.2 & $56.4 \mathrm{a}$ \\
\hline Lobel & 12 & 11.5 & 7.5 & $65.2 \mathrm{~b}$ \\
\hline CNR 118 & 12 & 100.0 & 0.0 & $0.0 \mathrm{c}$ \\
\hline \multicolumn{5}{|c|}{1991 Inoculation } \\
\hline \multicolumn{5}{|c|}{ Defoliation $(F=180.3 ; P \leq 0.001)$} \\
\hline S. Zanobi & 12 & 19.5 & 5.5 & $28.2 \mathrm{a}$ \\
\hline Lobel & 12 & 50.0 & 9.1 & $18.2 \mathrm{~b}$ \\
\hline Urban’ & 12 & 49.5 & 8.3 & $16.7 \mathrm{~b}$ \\
\hline CNR 118 & 12 & 90.0 & 4.7 & $5.2 \mathrm{c}$ \\
\hline \multicolumn{5}{|c|}{$\operatorname{Dieback}(F=201.8 ; P \leq 0.001)$} \\
\hline S. Zanobi & 12 & 8.5 & 2.4 & $28.2 \mathrm{a}$ \\
\hline Lobel & 12 & 35.5 & 11.6 & $32.7 \mathrm{~b}$ \\
\hline Urban & 12 & 36.5 & 10.0 & $27.4 \mathrm{~b}$ \\
\hline CNR 118 & 12 & 89.0 & 5.7 & $6.4 \mathrm{c}$ \\
\hline
\end{tabular}

${ }^{\mathrm{z}} \mathrm{N}=$ number of samples.

${ }^{\mathrm{x}} \mathrm{STD}=$ standard deviation

${ }^{{ }^{\mathrm{w}} \mathrm{CV} \%}=$ percent coefficient of variation. Means not sharing same letters are significantly different for LSD test $(P<0.05)$.

\section{Availability}

'San Zanobi' and 'Plinio' will be available from commercial sources under license from C.N.R. Inquiries can be addressed to Veneto Agricoltura Via Roma 3-4, 36030 Montecchio Precalcino (VI), Italy.

\section{Literature Cited}

Brasier, C.M. 1981. Laboratory investigation of Ceratocystis ulmi, p. 76-79. In: R.J. Stipes and R.J. Campana (eds.). Compendium of elm diseases. Amer. Phytopathol. Soc., St. Paul Minn.

Brasier, C.M. and S.A. Kirk, 2001. Designation of the EAN and NAN races of Ophiostoma novo-ulmi as subspecies. Mycol. Res. 105:547-554.

Columella, L.G.M. ca. 60 C.E. De re rustica. ed. Giulio Einaudi editore s.p.a., Torino Italy.

Heybroek, H.M. 1983. Resistant elms for Europe, p. 108-113. In: D.A. Burdekin (ed.). Research on Dutch Elm Disease in Europe. For. Commission Bul. No. 60. HMSO, London.

Heybroek, H.M. 1993. The Dutch elm breeding program, p. 16-25. In: M.B. Sticklen and J.L. Sherald (eds.).Dutchelm disease research. Springer Verlag, New York.

Mittempergher, L. 2000. Elm Yellows in Europe, p. 103-120. In: C.P. Dunn (ed.). The Elms: Breeding, conservation, and disease management. Kluwer Academic Press, Boston, Dordrecht, London.

Mittempergher,L. and N.La Porta 1991. Hybridisation studies in the Eurasian species of elm (Ulmus sp.). Silvae Genetica 40:237-243.

Royal Horticultural Society. 1966. Colourchart. Royal Hort. Soc., London.

Smalley, E.B. and R.P. Guries 1993. Breeding elms for resistance to Dutch Elm Disease. Annu. Rev. Phytopathol. 31:325-352. 